Brit. F. industr. Med., 1966, 23, 83

\title{
The Anaemia of Lead Poisoning: A Review
}

\author{
H. A. WALDRON
}

From the Medical Department, Vauxhall Motors Ltd., Luton, Beds. *

Lead intoxication has been recognized as a clinical entity since ancient times. Hippocrates (370 B.c.) was probably the first person to associate lead with clinical symptoms, since when the harmful effects of lead on the body have been well documented. Early observations culminated in the brilliant monograph of Tanquerel des Planches (1839) in which the clinical aspects of the disease were completely outlined and most of the early signs of the disease were mentioned. So complete was this work that virtually nothing has been added to des Planches's observations since their publication.

The earliest reference to lead anaemia was made in I83I by Laennec, who described thinness of the blood and pallor of the tissues in cases of lead poisoning at necropsy. The first direct evidence of the effect of lead on red blood cells was presented by Andral and Gavarret (1840), who counted the number of red blood cells in cases of lead poisoning and found the count to be much lower than normal.

Since these early reports a great deal of work has been undertaken to try to discover the means by which lead causes anaemia, but it is probably true to say that at the present time this mechanism is still not fully understood. This review is an attempt to draw together at least some of the theories which have been advanced in the past and to present them, it is hoped, in an easily accessible manner for future workers in this field.

\section{Classification}

The anaemia of lead poisoning is seldom severe, the haemoglobin level rarely falling below $60 \%$ or the red cell count below $4 \times 10^{6} / \mathrm{c} . \mathrm{mm}$. (Cantarow and Trumper, 1944). There is a considerable variation in the haemoglobin levels reported in the literature in cases of lead poisoning but the anaemia is usually said to be hypochromic. Thus Griggs (1964), in a study of 20 men with lead poisoning, found the anaemia to be mild and hypochromic with many reticulocytes and stippled cells present, although there was no correlation between the numbers of these cells and the degree of anaemia.

Saita, Fiocchi, and Cattaneo (1952) made an extensive study of $4 \mathrm{I}$ cases of lead poisoning as a result of which they were able to classify the anaemia into three categories. In the pre-clinical stage the anaemia was normocytic and normochromic with hypochromia developing in the acute stage of the disease. A few patients in the acute stage tended to develop macrocytosis but as the disease moved into a chronic stage, half the patients had a macrocytic, hypochromic anaemia. In the other half the

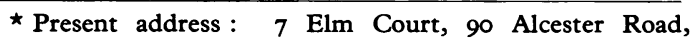
Moseley, Birmingham, 13 .

Received for publication October 6, 1965.
}

anaemia remained normocytic and normochromic. In children the anaemia is usually more severe and more pronouncedly microcytic and hypochromic, perhaps because lead poisoning in children is often associated coincidentally with a nutritional irondeficiency disease (Watson, Decker, and Lichtman, 1958).

The anaemia of lead poisoning has many of the characteristics of thalassaemia from which it must be carefully differentiated. This is of particular importance in the Mediterranean countries where the incidence of thalassaemia is high. Most of the work in this connexion has been carried out in France or Italy (Saita and Moreo, I959; Roche, Lejeune, Tolot, Mouriquand, Baron, Goineau, and Soubrier, 1960; Gaultier, Fournier, and Gervais, 1962; Gérard, Guerrin, and Roussel, 1964). Differentiation between the two states lies mainly in demonstrating the presence of haemoglobin $A_{2}$. In patients with thalassaemia this may be present in amounts up to $10 \%$ whereas in the normal adult this type of haemoglobin amounts to less than 3\%. Large amounts (40 to $90 \%$ ) of foetal haemoglobin ( $\mathrm{Hb} \mathrm{F}$ ) are also present in thalassaemia. There have been reports that $\mathrm{Hb} \mathrm{F}$ is also found in cases of human lead poisoning and in lead-poisoned rabbits (Buczkowski, 1964), but Lovisetto, Sibour, and 
Turco (1957) were unable to find it in 14 cases of plumbism, and Wolman and Bongiovanni (1956) in their review considered that only the normal adult haemoglobin ( $\mathrm{Hb} \mathrm{A}$ ) was present in lead poisoning. A finding of excessive urinary coproporphyrin excretion will distinguish the patients with lead poisoning from those with thalassaemia.

Lead anaemia has many of the features of a typical sideroblastic anaemia listed by MacGibbon and Mollin (1965), for example hypochromia, impaired maturation and defective haemoglobinization of red cells, raised serum iron, rapid plasma iron clearance with decreased cell uptake of ${ }^{59} \mathrm{Fe}$, and erythroblasts containing iron-staining inclusion bodies (sideroblasts). It is classified as a sideroblastic anaemia by Mollin (1965).

\section{Effects of Lead on Circulating Red Cells}

Osmotic Fragility A great deal of the early work on the pathogenesis of the anaemia of lead poisoning was carried out by Aub and his colleagues and reported in a series of classic papers (Aub, Reznikoff, and Smith, 1924; Aub, Minot, Fairhall, and Reznikoff, 1924; Aub, Fairhall, Minot, and Reznikoff, 1925; 1926). These authors found that normal washed or defibrinated red cells became more resistant to hypotonic saline after exposure to lead chloride solution. Cells that had been exposed to solutions of lead of concentrations as high as one part per 100,000 did not haemolyse in $0.1 \%$ saline whereas normal cells were completely haemolysed in $0.25 \%$ saline.

These observations on the effects of lead on the osmotic fragility of the red cell have been almost unanimously corroborated. Indeed the only dissenting voice seems to be that of Sroczyniski who induced chronic and acute lead poisoning in rabbits by injecting a $0.9 \%$ solution of alkaline lead acetate into the marginal vein of the ear (Sroczyński, 1959, 1963) and found that red cells from both groups of animals showed a marked decrease in resistance to hypotonic saline solutions. The resistance was decreased more markedly in the acute group than in the chronic group. Many other authors, however, have recorded a normal or increased resistance to hypotonic saline solutions (Pearse, 1926; Velicogna, 1933; Fullerton, 1952; Baron, 1954; Harris and Greenberg, 1954; Crepet, Rubino, and Gobbato, 1956; Rubino, Prato, and Fiorina, 1956; Clarkson and Kench, 1958b; Griggs and Harris, 1958; Tishkoff, Granville, Rosen, and Dameshek, I958), and the findings of Aub and his colleagues may be taken as being well confirmed.

Fullerton (1952), in her study of eight patients with plumbism, found that quantitative changes in fragility curves were altered pari passu with an increase in punctate basophil counts, but this observation has not been confirmed since. The changes in osmotic fragility induced by lead are, on the whole, slight, although the osmotic fragility of leaded red cells is more increased after sterile incubation for 24 hours (Harris, 1963; Griggs, 1964; Waldron, 1964).

The mechanism by which lead causes osmotic changes in red cells is not as yet understood. Lead affects the cation permeability of the cell membrane resulting in increased potassium loss (Joyce, Moore, and Weatherall, 1954; Vincent and Blackburn, 1958). At concentrations of $100 \mu \mathrm{M} / 1 ., \mathrm{K}^{+}$loss is much increased, the effect decreasing with time (Passow and Tillmann, 1955). It is thought that the increased osmotic resistance may indicate that more water could enter the cells before a critical spheroidal form is reached and lysis occurs (Griggs, 1964), and it may be possible to equate the changes in osmotic fragility with the alterations in permeability since changes in permeability may affect the water relations of the cell.

Mechanical Fragility Although Aub and his colleagues found that the osmotic fragility of the leaded red cell was decreased, they found, by contrast, that the mechanical fragility was much increased. Thus, when leaded red cells were rotated in a tonometer or centrifuged, haemolysis due to the rolling of the red cells on the glass was markedly increased compared with normal red cells similarly treated. Shaking the cell suspensions in a shaking machine gave similar results. This double action of lead-decreasing the osmotic fragility whilst increasing the mechanical fragility-had also been seen by Fici (1920, I921a and b).

From their observations Aub et al. concluded that leaded red cells were less able to withstand the dynamic trauma consequent upon passage through the capillaries and so broke up more readily than normal cells, giving rise to the anaemia seen in lead poisoning. This conclusion was in accord with the general concensus of opinion at the time, since early work by Heubel (1871) and Bouchard (1873), later confirmed by Rauch (1922), had indicated that lead anaemia was due to the destruction of circulating red cells.

Aub and Reznikoff (1924) proposed that the damage to the red cell envelope which brought about the increased mechanical fragility was caused by the liberation of free acid when lead combined with the inorganic phosphate of the red cells or plasma according to the following equation

$$
3 \mathrm{PbCl}_{2}+\underset{\mathrm{Pb}_{3}\left(\mathrm{PO}_{4}\right)_{2}}{2 \mathrm{Na}_{2} \mathrm{HPO}_{4}=}+4 \mathrm{NaCl}+2 \mathrm{HCl} .
$$


This hypothesis was challenged by Maxwell and Bischoff (I929a and b) after they had observed changes in red cells after exposure to lead similar to those described by Aub et al. but without the liberation of free acid. Maxwell and Bischoff believed that the injury to the cells might be due to the formation of lead diglycerophosphate which is more active than the tertiary phosphate. More recent work by Clarkson and Kench (1958a) has indicated that lead interacts with red cells in a process involving the coagulation and flocculation of a peptized lead phosphate sol on the cell membrane.

Since Aub's original reports there has been a considerable division of opinion on the effect of lead on the mechanical fragility of the red cell. Goldblatt and Goldblatt (1956) were of the opinion that the fall in numbers of red cells in lead poisoning was almost certainly due, in part at least, to an effect of the metal ion on the red cell envelope rendering it deformed and more vulnerable to mechanical injury. Teisinger, Zumanova, and Zezula (1958) also stated that the anaemia was caused by haemolysis due to the action of lead on the cell membrane, but Clarkson and Kench (1958b) concluded from their studies that in vivo lead would be unlikely to produce detectable damage to the circulating red cell due, they thought, to the protective action of excess phosphate in the plasma. They were of the opinion that any damage caused to the red cells by lead would be confined entirely to the formative stages in the bone marrow. Baron (1954) found the mechanical fragility of the red cells to be normal in Io cases of lead poisoning, and this was also the finding of Rubino et al. (1956) in the 16 patients they studied. Sutherland and Eisentraut (I956) induced chronic plumbism in dogs by intraperitoneal injection of lead acetate, and they noticed an increase in mechanical fragility although this was not correlated with the degree of anaemia present nor with the results of Coombs' test.

An increase in mechanical fragility was reported in cases of human plumbism by Harris and Greenberg (1954) and by Fratianne, Griggs, and Harris (1959), but later Griggs (1964) showed that the mechanical fragility in Io patients with lead poisoning did not vary considerably from the normal range. de Kretser and Waldron (1963) determined the mechanical fragility index in a group of 68 lead workers and found that the cells from these individuals tended to be less fragile than normal.

The reports of Harris and Greenberg (1954) and Fratianne et al. (1959) do not contain experimental details, and it is not possible to say whether their experiments were carried out with completely fresh blood. Sutherland and Eisentraut (1956) also make no mention of this point. de Kretser and Waldron
(1963) found that the mechanical fragility index of red cells was markedly increased on standing, and the disparity between their results and those of the earlier workers would be explained if the blood used by the older workers was not fresh, i.e., had stood for more than one hour.

There is also no mention in Harris's reports of haemoglobin levels. de Kretser and Waldron (1963) showed that anaemia per se brought about an increase in the mechanical fragility of red cells and they suggested that any increase in the mechanical fragility of red cells in patients with plumbism might be a post hoc rather than a propter hoc phenomenon.

There is general agreement, however, that sterile incubation for 24 hours causes an increase in the mechanical fragility of leaded red cells. In four of the 10 cases described by Griggs (1964), incubation caused a more than normal increase in mechanical fragility $(16.5 \%, 19.7 \%, 22.2 \%$, and $26 \%$ compared with a mean control of $10.5 \pm 3.5 \%$ ). Waldron (1964) confirmed this, but the changes found in leaded red cells were not enough to suggest that an increase in mechanical fragility was a significant factor in the production of lead anaemia.

Fratianne et al. (1959) were able to produce changes in normal red cells by incubating them for short periods with lead chloride in vitro, but relatively high concentrations of lead had to be used, more than $15 \mu \mathrm{g}$. $\mathrm{Pb}^{++} / \mathrm{ml}$. cells, according to Griggs (1964). Recently de Kretser and Waldron (1965) have found that below a concentration of Io $\mu \mathrm{g} . / \mathrm{ml}$. lead causes the mechanical fragility index of normal red cells to be decreased, but above this concentration the mechanical fragility is increased, reaching a maximum at about $45 \mu \mathrm{g} . \mathrm{Pb}^{++} / \mathrm{ml}$.

With this in mind it is interesting to consider the levels of lead found in the bone marrow. There is some evidence to suggest that the concentration of lead is much higher in the bone marrow than in the peripheral blood. Westermann, Pfitzer, and Jensen (1963) showed that in a group of patients with lead poisoning with blood lead levels of 0.7 to $\mathrm{I} \cdot 3 \mu \mathrm{g}$. $/ \mathrm{ml}$., the corresponding marrow concentrations were 42 to $92 \mu \mathrm{g}$. $/ \mathrm{ml}$. At these concentrations it may be that lead does have some effect on the membrane of the developing red cell. A number of glycolytic reactions are thought to proceed in the cell membrane (Prankerd, 196I) and since some of these reactions may involve sulphydryl (-SH) group enzymes it would not be unreasonable to expect lead to inhibit some at least of these reactions in view of its known affinity for -SH groups (Wilkinson, 1962). Any interference with the integrity of the red cell membrane may well result in a shortened cell life but the evidence that this is indeed the case is equivocal to say the least. 


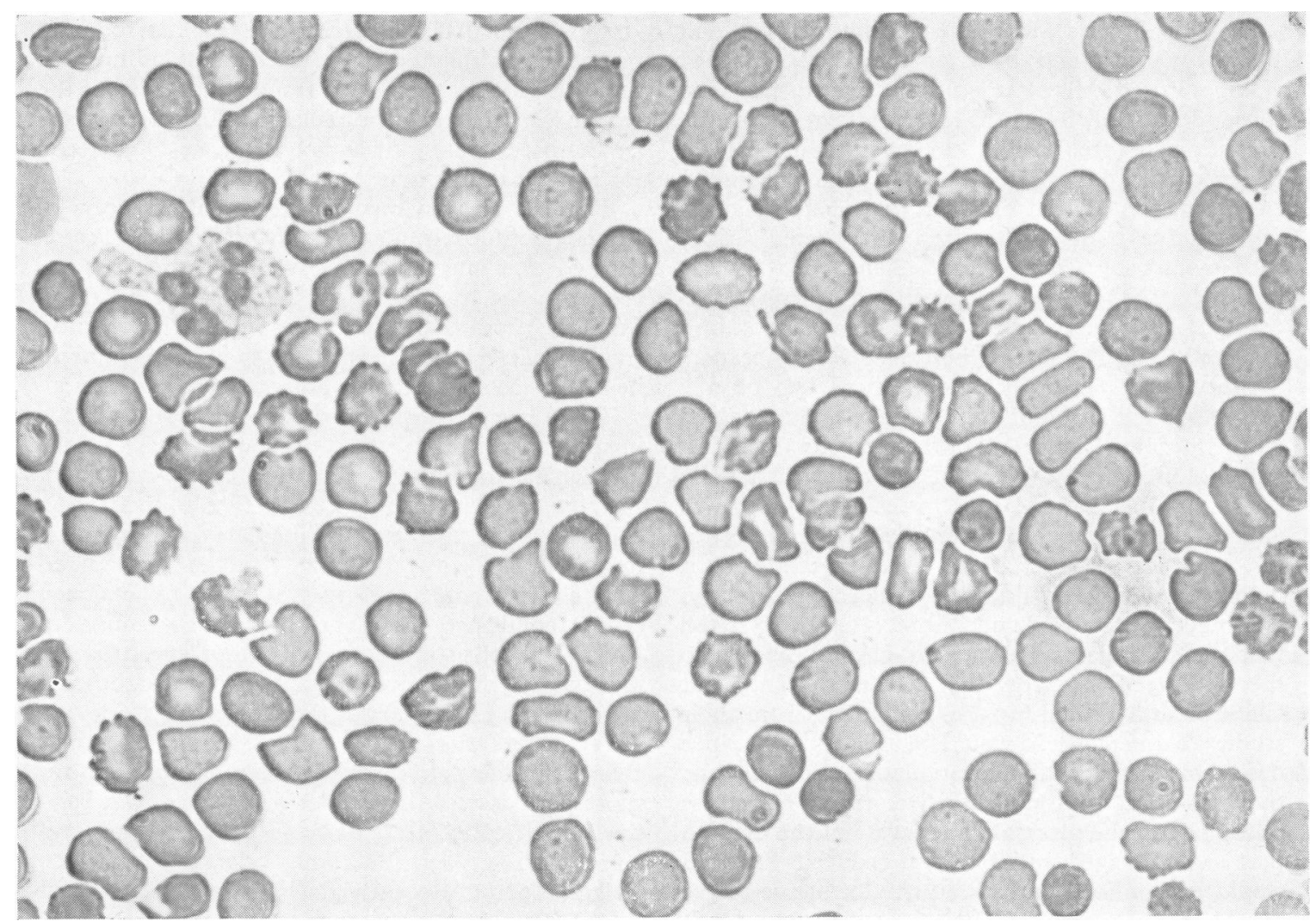

FIG. I. Photomicrograph of red cells incubated with lead (20 $\mu \mathrm{g} . / \mathrm{ml}$. blood) showing distortion produced. Film fixed and stained with Leishman stain. $\times$ I,000.

However, large concentrations of lead have been shown to produce morphological changes and destruction of red cells when administered in vitro or in vivo. At concentrations of $0.15 \mathrm{M} \mathrm{Pb}^{++}$haemolysis was observed microscopically in the spherical and hexagonal crenate forms produced although smaller crenate forms did not haemolyse (Vincent, 1958). Incubating red cells with lead (20 $\mu \mathrm{g}$. $\mathrm{Pb}^{++} / \mathrm{ml}$. for 30 minutes) has been found by the author to produce morphological changes in red cells although haemolysis was not observed (Fig. I). The 'treatment' of malignancy with lead solutions produced some interesting reports on the effect of lead on circulating red cells. Brookfield (I928) investigated the effects of lead preparations used for such treatment on the blood of patients with cancer. The patients he studied were given 25 to $100 \mathrm{mg}$. $\mathrm{Pb}^{++}$intravenously in one of two suspensions over a varying period of time. The effects varied from patient to patient. Usually a positive van den Bergh reaction was obtained after the first or second injection and there was an increase in urobilin excretion.
Brookfield demonstrated that the red cell count was diminished after the injection of lead, in a few cases by $-21 \%$ in half an hour after the injection. The red cell count rapidly returned to normal due to increased marrow activity, indicated by an increase in reticulocytes. Morphologically the cells were remarkably distorted with folding and clumping, some looking as though small pieces had been 'bitten out of them with a punch', findings previously reported by Maurel (I9I2) after blood from rabbits and man had been treated with lead acetate in vitro. Gould, Kullman, and Shecket (1937) followed 17 cancer patients given a total of 535 to $805 \mathrm{mg}$. $\mathrm{Pb}^{++}$over a two- to four-week period and a further five given 175 to $280 \mathrm{mg}$. over the same period. A progressive anaemia was noted in 16 of the 22 patients. Bell, Williams, and Cunningham (1925) also found anaemia in cancer patients given lead intravenously, and Bell (1930) found a reduction of $10^{6}$ red cells in some patients one hour after a single injection.

Results comparable to these are found in cases of 
lead poisoning resulting from the ingestion of large doses of lead, often single doses, taken either with suicidal intent or by accident. There is a rapidly developing anaemia in such cases (Laporte, Meyer, and Bousser, 1939; Riedl, 194I ; Strickland, 1948; Bastrup-Madsen, 1950; Wade and Burnum, 1955; Mellemgård and Sørensen, 1955; Karpatkin, 1961) with occasional jaundice suggesting haemolysis (Karlog and Møller, 1958). A raised serum bilirubin was observed by Crutcher (1963) in seven patients with plumbism following the ingestion of leadcontaminated 'moonshine' whisky. This, he thought, gave support to the theory that lead caused haemolysis. Davidson (1932) reported one case of lead poisoning due to drinking contaminated water; jaundice and a very raised serum bilirubin were noticed due, partly at least, to increased blood destruction. Jaundice was also found in one patient by Henderson (1952) and in a fatal case of a woman who had taken lead as an abortifacient by Dérobert and Hadengue (1947). Increased bilirubinaemia has occasionally been reported in patients with lead poisoning from other sources. Cantarow and Trumper (1944) found that levels ranging from $I \cdot O$ to $2.3 \mathrm{mg}$./ $100 \mathrm{ml}$. were not uncommon, and raised levels have also been reported by Heubel (1871), Schmidt-Kehl (1927), Klima and Seyfried (1937), Vigliani and Angeleri (1935), and Tishkoff et al. (1958) despite a note by Hijmans van den Bergh (193I) that the serum bilirubin is usually low or normal in lead poisoning.

In an investigation of nine patients with industrial lead poisoning, Maugeri (I940) found a raised serum bilirubin and increased excretion of stercobilinogen and urobilinogen. He concluded that lead anaemia was haemolytic in type on the basis of this study. Increased faecal urobilinogen excretion was observed in lead-poisoned guinea-pigs by Baikie (1954). Previous work by London, West, Shemin, and Rittenberg (1950) and Grinstein, Wikoff, Pimenta de Mello, and Watson (1950b) using ${ }^{15} \mathrm{~N}$ glycine had shown that faecal stercobilinogen was derived in part from sources other than the haemoglobin of circulating red cells (at least $12 \%$ (London et al., 1950); 40\% in a case of untreated pernicious anaemia (London and West, 1950) ) but, despite this, Baikie found that the increased urobilinogen excretion in the poisoned animals was closely correlated with the drop in haemoglobin, and he thought that haemolysis played an important part in the pathogenesis of the anaemia of lead poisoning.

Simpson, Seaton, and Adams (1964), in an exhaustive study of a single case of lead poisoning in a lead burner presenting with neurological involvement, reported raised faecal and urinary urobilinogen excretion. Despite this, red cell fragility studies were normal and the radio-chromium halflife of the cells was normal, and they did not think that the urobilinogen excretion was due to hyperhaemolysis although they could suggest no alternative explanation.

Some further evidence for the haemolytic nature of the anaemia of lead poisoning, however, was put forward by McFadzean and Davis (1949). In a previous paper (McFadzean and Davis, 1947) they had observed red cells containing iron-staining inclusion granules in a number of acquired haemolytic conditions including lead poisoning. They extended this work using guinea-pigs poisoned with lead acetate and discovered many siderocytes in the blood of these animals, the proportion being much higher in the bone marrow than in the peripheral blood. Splenectomy was performed on some of the animals and it was found that this gave rise to a very considerable increase in the frequency of stippling in the peripheral blood and in the number of siderocytes present. After splenectomy the red cell count rose but there was no change in bone marrow stippling. McFadzean and Davis (1949) suggested that lead was taken up by erythroblasts in the marrow as a result of which defective cells (siderocytes and stippled cells) were produced which were taken up by the spleen and other parts of the reticulo-endothelial system and destroyed, this action by the spleen producing a haemolytic anaemia. There was some support for this theory in the work of Kin (1939) who had reported that the spleen and liver contained some specific chemical substances able to decrease erythrocytes after the injection of lead acetate.

In their earlier paper, McFadzean and Davis (1947) had suggested that the iron granules found were produced by an abnormal mechanism of haemoglobin catabolism peculiar to haemolytic conditions. This part of their thesis was cast in doubt by the later work of Kaplan, Zuelzer, and Mouriquand (1954) who found the presence of visible iron to be a normal phase in intracellular iron metabolism, associated with haemoglobin synthesis rather than breakdown. The later results of McFadzean and Davis (1949) were confirmed by Pirrie (1952) using techniques similar to those of McFadzean and Davis. He also used trypan blue to block the reticulo-endothelial system of his intoxicated animals and found that this, too, resulted in a greatly increased number of stippled cells in the circulation. He found that the histological appearance of the spleens of the animals resembled that seen in haemolytic anaemias in general, and his conclusions as to the effect of lead on the erythron were the same as those of McFadzean and Davis.

Some doubt was cast on this hypothesis, however, 
by Douglas and Dacie (1953), who could find no evidence that the spleen filtered off siderocytes but, despite this, Goldblatt (1955) still held that in lead poisoning abnormal red cells produced in the marrow were rapidly taken up and destroyed by the spleen and other parts of the reticulo-endothelial system. Further doubts were cast by Brüschke (1959, 1962) who, although confirming the experimental results of McFadzean and Davis (1949) and Pirrie (1952), thought that the spleen did not remove the defective red cells but merely the iron-staining granules. He referred to the earlier work of Crosby (1957) who had transfused blood containing many siderocytes into patients with and without spleens. The transfused cells were tagged with ${ }^{51} \mathrm{Cr}$, and it was found that in those patients with spleens the siderotic granules gradually disappeared leaving the red cell membrane intact. There was further evidence to support Brüschke's contention in the work of Vorhaus and Turner (1957) who showed that mature nucleated avian cells injected into guinea-pigs extruded their nuclei while in the spleen without undergoing apparent destruction, and also in the experiments of Jandl and Tomlinson (1958) who showed that lecithinized spherocytes were retained in the spleen and returned to the circulation after correction of their defects. Since the sinusoids of the spleen are morphologically identical with those of the bone marrow (Weiss, 1957) it is not unreasonable to assume, as Crosby (1959) suggests, that the spleen may provide a point at which defects in circulating red cells are removed to compensate for any inefficiencies in the mechanisms controlling the release of newly formed red cells from the bone marrow.

The evidence seems to suggest therefore that McFadzean and Davis (1949) and Pirrie (1952) misinterpreted the results of their experiments. It is more likely that siderocytes are 'matured' by the spleen (Bessis and Breton-Gorius, 1962) with consequent removal of siderotic granules, rather than destroyed by it.

\section{Inhibition of Haem and Protoporphyrin Synthesis}

Effect on Iron Metabolism Other theses have been advanced to account for the production of anaemia by lead. Lourau (1946), for example, did not think that lead caused destruction of red cells but, after conducting experiments with leadpoisoned rabbits, thought it prevented the synthesis of an anti-pernicious factor by the inhibition of an enzyme located in the gastro-intestinal tract (Lourau, 1947a, b, and c). This theory has attracted little attention, but one advanced by Rimington in
1938 has now become widely accepted. Rimington advanced the hypothesis that lead interfered with a specific enzyme system responsible for incorporating iron into the protoporphyrin IX molecule to form haem. (He discounted the haemolytic action of lead after finding normal faecal urobilinogen excretion in lead-poisoned animals, but, as already discussed, this is not an altogether reliable index of the rate of degradation of circulating haemoglobin.)

If this hypothesis is correct, then one would expect to find raised levels of erythrocyte protoporphyrin and non-haemoglobin iron stores in cases of lead poisoning, and this is indeed the case. Raised erythrocyte protoporphyrin levels have been reported by Roth (1935), Vigliani and Angeleri (1935), Vannotti and Imholz (1939), Watson (1950), Schmid, Schwartz, and Watson (1950), Pecora (1954), Larizza and Ventura (1954), Grazianni, Fusco, and Rossi (1954), Rutino and Prato (1955), Saita, Moreo, and Petrocchi (1956), Grazianni, Pecora, and Rossi (1956), Watson et al. (1958), Rubino, Pagliardi, Prato, and Giangrandi (1958), Rubino (1962), and Sano, Inoue, Harada, and Orita (1960), and raised serum iron values by Vannotti and Imholz (1939), Prader (1948), Grazianni et al. (1954), Larizza and Ventura (1954), Saita et al. (1956), Grazianni et al. (1956), Rubino et al. (1958), Tishkoff et al. (1958), Hutchison and Stark (196I), David (1963), and Zegarski (1963). Vigliani and Angeleri (1935) found that the increase in protoporphyrin was accompanied by a simultaneous rise in serum bilirubin. They concluded that the porphyrin was derived as a result of considerable haemolysis. This view was discounted by Vannotti (1954) who thought that if any haemolysis were caused by lead it would be insufficient to account for the rise in protoporphyrin found in lead poisoning.

There is no correlation between the levels of protoporphyrin and serum iron (Saita et al., I956) but Zegarski (1963) found a distinct relation between urinary coproporphyrin excretion and serum iron values in $3 \mathrm{I}$ cases of lead poisoning.

Some early opposition to Rimington's theory was provided by Kench, Gillam, and Lane (1942) and later by Lemberg and Legge (1949). These workers drew attention to the disproportion between amounts of coproporphyrin III excreted in lead poisoning and the degree of disappearance of haemoglobin in anaemic cases. Kench et al. (1942) performed a direct experiment on Kench and found that the daily intake of $20 \mathrm{mg}$. of lead acetate for 38 days produced no change in blood haemoglobin levels although the daily urinary coproporphyrin excretion was raised from $22 \mu \mathrm{g}$. to $268 \mu \mathrm{g}$. They concluded that their results mitigated against 
Rimington's theory despite finding a very raised blood protoporphyrin level which the theory predicts.

Kench, Lane, and Varley (1952) were also critical of Rimington's theory. They believed that the anaemia of lead poisoning was haemolytic in character and they based this conclusion mainly on the finding of coproporphyrin $I$ in the urine of seven bath enamellers with lead poisoning. These authors were the first to demonstrate coproporphyrin I in the urine of patients with lead poisoning, it having been thought previously that only coproporphyrin III was present in such persons (Grotepass, 1932; Watson, 1936). The significance of this finding was that coproporphyrin I had previously been found in excess only in haemolytic conditions (Watson, I937; Dobriner and Rhoads, I940; Watson and Larson, 1947; Grinstein, Kamen, Wikoff, and Moore, 1950; Rimington, 1952), and Rimington (1936) had advanced the theory that the urinary excretion of coproporphyrin I might provide an index of the rate of haemopoiesis.

Kench et al. (1952) studied their workers for 130 days following cessation of exposure to lead. They found that coproporphyrin I accounted for about $30 \%$ of the total porphyrin excreted during that time. In four cases the urine obtained on the 329th and 330th days after removal from exposure contained $42,67,117$, and $348 \mu \mathrm{g}$./1. of coproporphyrin I (constituting 20 to $47 \%$ of total porphyrin). They maintained that lead interfered with the maturation of the erythroid marrow cells giving rise to stippled cells broken down by the reticulo-endothelial system, the haemolytic action being confirmed by the excess of coproporphyrin I excreted. It is questionable, however, whether the excretion of coproporphyrin I nearly a year after exposure to lead had ceased would be due to abnormal destruction (Goldblatt and Goldblatt, 1956). It is more likely that these workers were seen in a stage of active regeneration of haemoglobin.

Coproporphyrin I has been demonstrated in the urine of cases of clinical plumbism and in leadpoisoned animals since Kench et al. (1952) first reported it. Watson (1964) states that up to $10 \%$ coproporphyrin I may be excreted in the urine of cases of lead poisoning, and various proportions of coproporphyrin I were found by the author in Io lead workers having considerable exposure to lead, using techniques similar to those of Kench et al. (1952) (Table I). Holeček (1957) found small amounts of coproporphyrin I, but unfortunately his data were qualitative only. Sümegi, Goreczky, and Roth (1956) found that 20 to $25 \%$ of the coproporphyrin excreted in the urine of lead-poisoned rabbits was isomer I, and Weatherall (I952) thought
TABLE I

URINARY Coproporphyrin ANALYSIS IN IO CASES OF INDUSTRIAL LEAD INTOXICATION

\begin{tabular}{cccr} 
Case No. & $\begin{array}{c}\text { Total Copro- } \\
\text { porphyrin }(\mu g . / l .)\end{array}$ & \multicolumn{2}{c}{ Isomer (\%) } \\
\cline { 3 - 4 } & & $I$ & $I I I$ \\
\hline$I$ & 1105 & 51 & 49 \\
2 & 412 & 10 & 90 \\
3 & 251 & 0 & 100 \\
4 & 566 & 10 & 90 \\
5 & 485 & 11 & 89 \\
6 & 607 & 0 & 100 \\
7 & 3047 & 0 & 100 \\
8 & 1397 & 0 & 100 \\
9 & 949 & 10 & 90 \\
10 & 499 & 0 & 100
\end{tabular}

some of the coproporphyrin excreted by such animals might be isomer I (about $10 \%$ on a qualitative basis) but later, in a further series of experiments, Comfort and Weatherall (1953) found only isomer III.

The finding of coproporphyrin I in the urine from cases of lead poisoning seems established, but the work of Grinstein and his colleagues indicates that it is not there as a result of increased haemoglobin breakdown. In one series of experiments (Grinstein et al., 1950a), ${ }^{15} \mathrm{~N}$-labelled glycine was administered to dogs, and it was shown that both the circulating haemoglobin and the excreted coproporphyrin I contained a high proportion of ${ }^{15} \mathrm{~N}$. Intravenous injection of the labelled haemoglobin from these dogs into other dogs treated with phenylhydrazine led to no significant increase of labelled coproporphyrin I. This confirmed that the coproporphyrin I excreted in the earlier experiment had not come from haemoglobin breakdown but had been synthesized from the labelled glycine. Similar experiments (Grinstein et al., 1950b) on leadpoisoned animals indicated that coproporphyrin III also derived from ingested ${ }^{15} \mathrm{~N}$ glycine and not from preformed haemoglobin. The results of these experiments confirmed earlier work by Björkman (I94I) who administered haemoglobin to lead-poisoned animals with no subsequent effect on their porphyrin excretion. Kark and Meiklejohn (1942) injected haemoglobin into two patients with lead poisoning and found an increase in plasma bilirubin identical with that found in normal subjects (Gilligan, Altschule, and Katersky, 194I). There was no increase in porphyrin excretion and they were of the opinion that these results mitigated against the theory that lead anaemia is haemolytic in character.

Watson (1950) drew attention to experiments in which there is a striking decrease of coproporphyrin in the red cells of lead-poisoned rabbits as they mature and leave the bone marrow (Schmid, 
Schwartz, and Watson, 1950), although this may be preceded by a transient increase (Schmid, Hanson, and Schwartz, 1952). Watson thought that the increase in urinary porphyrin excretion was less likely to be due to destruction of the developing cells than to the liberation of porphyrin from intact cells, since an enormous number of cells would need to be destroyed to supply the amounts of coproporphyrin excreted in the urine.

Despite a recent statement by Mann (1962) that the coproporphyrin excreted in the urine of cases of clinical plumbism is present as a result of haemoglobin breakdown, it seems extremely unlikely that this is, in fact, the case, and this must mitigate against the conclusions of Kench et al. (1952).

Further arguments for and against the validity of Rimington's theory have come from workers using isotope techniques to study haem synthesis who have also investigated the effects of lead on haem and protoporphyrin formation. The results of those studies where fully quantitative data were given (Rimington, 195 I Dresel and Falk, 1954, 1956a and b; Eriksen, 1955; Goldberg, Ashenbrucker, Cartwright, and Wintrobe, 1956; Kassenaar, Morell, and London, 1957; Grinstein, Bannerman, and Moore,
1959; Klein, 1962) are summarized in Table II. Various systems were used, but it will be seen that generally lead did inhibit both haem and protoporphyrin synthesis, the degree of inhibition depending on the concentration of lead present and to some extent on the system used. Not all authors, however, considered that the inhibition of haem synthesis was due to the prevention of incorporation of iron into the protoporphyrin molecule. Dresel and Falk (1956a) thought that lead inhibited the formation of a precursor of haem rather than the incorporation of iron into protoporphyrin. (An earlier finding by these authors (Falk and Dresel, 1952) that lead stimulated free porphyrin synthesis was considered to be due to an artefact in the system used.) Eriksen (1955) also thought that the inhibition of haem synthesis by lead was not due to the mechanism proposed by Rimington but rather to a diminished formation of the protein moiety of haem, and Aldrich, Labbe, and Talman (1955) were of the opinion that such an effect of lead offered a better explanation of the widespread symptoms of plumbism than that proposed by Rimington. Some evidence to support Eriksen's view is given in some recent work of Trakatellis, Heinle, Montjar,

TABLE II

Summary of Effects of Lead on HaEm and Protoporphyrin Synthesis

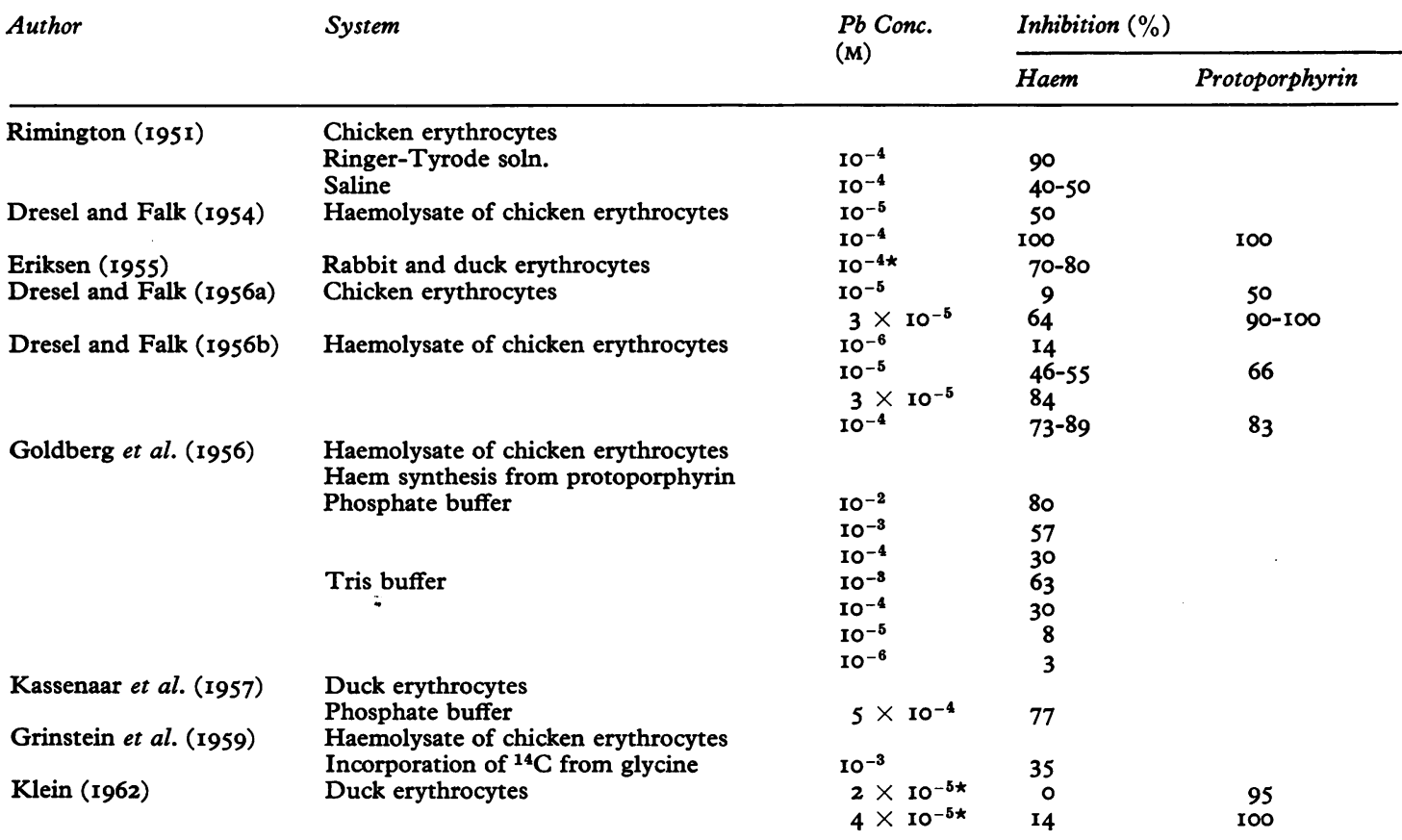

Concentrations of lead are given as lead acetate except when denoted $\star$, when concentrations are given as $\mathrm{Pb}^{++}$. All syntheses are from glycine as substrate except where otherwise stated. 
Axelrod, and Jensen (1965). These authors added lead acetate in a concentration of $5.7 \times 10^{-5} \mathrm{M}$ to a system of rat reticulocytes and found that lead caused a very rapid breakdown of polysomes $(40 \%$ in one hour, $72 \%$ in five hours). Since the polysomes are known to be able to synthesize the polypeptide chains of haemoglobin (Burka and Marks, I964), Eriksen's conclusions seem well founded.

Other workers, however, are firm in their support of Rimington's original hypothesis. Baron (1954) considered that the failure to incorporate iron into protoporphyrin was the most important cause of lead anaemia. Sano (1958a) and Heilmeyer (1959) both reported that lead blocked iron incorporation into protoporphyrin, but Sano thought that the inhibition of iron incorporation into the porphyrin ring was a secondary effect of lead. In a later work (Sano, 1958c) in which high erythrocyte protoporphyrin levels were found both with normal red cell counts and haemoglobin levels and with anaemia, he suggested that lead caused a hypersynthesis of porphyrin taking a course different from that of normal haem formation. Gajdos-Török, Gajdos, and Bénard (1958), using cells from rabbits treated with phenylhydrazine, found that lead (as lead acetate) completely inhibited the enzyme responsible for this incorporation (haem synthetase), probably by incorporating with free sulphydryl groups necessary for the activation of the enzyme (Schwartz, Cartwright, Smith, and Wintrobe, 1959). This finding was in accordance with the earlier work of Bénard, Gajdos, and Gajdos-Török (1958) who had shown that virtually no radio-iron was incorporated in vitro into the haemoglobin in red cells from lead-poisoned rabbits although protoporphyrin synthesis still took place. Later, Gajdos and Gajdos-Török (1958) found that iron was not incorporated into protoporphyrin in vivo using rabbits with experimental lead poisoning.

Although there seems no doubt that lead inhibits haem synthesis-by whatever means-in vitro, there is some evidence to suggest that its effect in vivo may not be the same as that observed in vitro. Caccuri, Pecora, Fati, and Vecchione (1958) found that the addition of homogenized tissue from animals with lead poisoning to a system of intact red cells and glycine stimulated the synthesis of protoporphyrin. Later, using the same system but without the homogenized tissue, they found that the addition of lead nitrate completely inhibited the synthesis of protoporphyrin (Pecora, Fati, and Vecchione, 1960). They advanced the theory, earlier put forward by Pecora (1954), that the effect of lead on protoporphyrin synthesis in vitro was different from that in vivo. In a more recent paper Pecora and his colleagues (Pecora, Fati, Molé, and Pesaresi, 1963) reported a study on the effect of lead on delta-aminolaevulinic acid dehydrogenase (ALAd) prepared from the bone marrow of rabbits. Weak concentrations of lead $\left(\mathrm{IO}^{-4}\right.$ to $\left.\mathrm{IO}^{-11} \mathrm{M}\right)$ stimulated protoporphyrin synthesis but inhibited it at a concentration of $10^{-2} \mathrm{M}$. This they regarded as conclusive evidence that lead stimulates protoporphyrin synthesis in vivo since, they said, lead is found in low concentrations in the bone marrow. The work of Westermann et al. (1963), however, suggests that lead is present in high concentrations in the bone marrow and this must throw some doubt on the conclusion of Pecora and his colleagues.

It is worth noting at this point that earlier stages in haem synthesis are also affected by lead (Fig. 2), notably the production of ALA from porphobilinogen, but it is not proposed to comment on this in this paper. The subject has been well dealt with by Haeger-Aronsen (1960) in her excellent monograph, and more recently by Chisolm (1964).

Extracellular iron metabolism is unaffected by lead. Iron is cleared from the plasma of patients with lead poisoning at a rapid or normal rate (Beck, Lanini, and Béraud, 1955; Boyett and Butterworth, 1962; Simpson et al., 1964). This is not always so in children. Watson et al. (1958) found abnormally low serum iron values in 13 children with lead poisoning. The total iron-building capacity of the

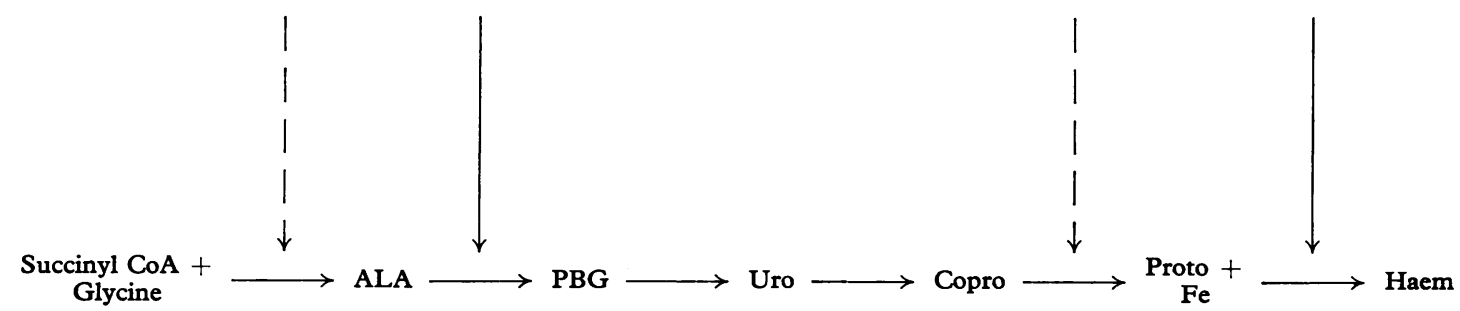

FIG. 2. Scheme showing main steps in haem synthesis. Solid arrows indicate stages inhibited by lead; broken arrows indicate stages at which inhibition is thought to take place, but evidence is inconclusive.

ALA = delta-aminolaevulinic acid; $\quad$ PBG $=$ porphobilinogen; $\quad$ Uro $=$ uroporphyrinogen;

Copro = coproporphyrinogen; $\quad$ Proto $=$ protoporphyrinogen 
serum was variable, but the mean value for the group was normal $(285 \mu \mathrm{g}$./100 ml.). Leikin and Eng (1963), however, who studied plasma iron clearance in seven children with lead poisoning, found that in the three with the longest history of exposure the plasma iron clearance time was prolonged and the rate of incorporation of iron into the blood cells was decreased. The four children with shorter exposure were found to have normal or increased iron-turnover results. These studies confirmed that extracellular iron metabolism is normal in lead poisoning but, with long exposure, erythroid hyperplasia may result in a decreased turnover of iron. An increase in plasma iron clearance has been noted in animals with lead poisoning by Paolino, Resegotti, Sartoris, and Infelise (1963).

Sroczyński, Jonderko, and Watras (1964) produced additional evidence that lead impairs the rate of incorporation of iron into mature and immature red cells. Using ${ }^{59} \mathrm{Fe}$ they found that lead prevented the incorporation of iron into the red cells of leadpoisoned rabbits although this inhibition was apparently prevented by the administration of ethylene diamine tetracetate (EDTA). Lead has also been found to impair the incorporation of iron into circulating red cells in cases of human lead poisoning (Boyett, Pittman, and Butterworth, 1960; Boyett and Butterworth, I962). In their case of lead poisoning, Simpson et al. (1964) found that, although iron passed normally to the marrow, only $40.9 \%$ was utilized as against a normal utilization of 68 to $86 \%$.

Jandl, Inman, Simmons, and Allen (1959) showed that the uptake of ${ }^{59} \mathrm{Fe}$ by human reticulocytes was almost completely inhibited by the addition of $5 \times 10^{-4} \mathrm{M} \mathrm{Pb}^{++}$but only slightly diminished $(-20.6 \%)$ by $\mathrm{IO}^{-4} \mathrm{M} \mathrm{Pb}^{++}$. The incorporation of ${ }^{59} \mathrm{Fe}$ into haemoglobin, however, was almost entirely prevented, with the consequence that the amount of iron in the red cell membrane was greatly increased. Reticulocytes from bled rabbits incubated with $\mathrm{IO}^{-4} \mathrm{M} \mathrm{Pb}^{++}$showed only a moderate diminution in cellular uptake of ${ }^{59} \mathrm{Fe}$ but there was a striking increase in the amount of iron in the stromal fraction of the hydrolysed centrifuged cells. This confirmed earlier work by Bessis and Breton-Gorius (1957C) who had also demonstrated an accumulation of iron in the stroma of immature red cells in cases of plumbism.

Allen and Jandl (1960) extended their earlier work using washed rabbit reticulocytes. They found that when iron was taken up by these cells it was first associated with various particulate fractions (stroma, mitochondria, and microsomes) before being gradually released into the soluble cytoplasm to become incorporated into a transient non- haemoglobin protein phase and then into haemoglobin. They found that lead allowed iron to accumulate in the particulate fractions but that it blocked the entry into the non-haemoglobin phase and into haemoglobin. This work was confirmed by Gajdos-Török, Gajdos, and Bénard (1960) and later by Lothe and Falbe-Hansen (1963). Lothe and Falbe-Hansen found that haemoglobin synthesis in lead-poisoned rabbits was greatly diminished, although haemoglobin precursors could still take up iron. They concluded that lead blocked the transfer of iron from a ferritin phase, not associated with the stroma, to an electrophoretically fast-moving fraction associated with the mitochondria. Greenough, Peters, and Thomas (I962) studied the effects of lead on intracellular iron metabolism in vitro using a system derived from dog and human bone marrow. A minor fraction was isolated from this system which appeared to be a precursor of haemoglobin. Lead acetate $\left(\mathrm{IO}^{-4} \mathrm{M}\right)$ did not block incorporation of iron into this fraction but it did block the entry of iron into haemoglobin. Korst, Frenkel, and Wilhelm (1962), using short-term marrow culture techniques, found that serum from anaemic animals increased the uptake of iron by the marrow cells, but uptake was inhibited by lead. Cooper (cit Griggs, 1964) prepared mitochondria from the reticulocytes of anaemic rabbits and found that lead inhibited the mitochondrial uptake of iron. This result is somewhat at variance with the evidence obtained using the electron microscope which indicates that iron stores are increased in the mitochondria in lead poisoning. These electron microscope studies have shown that the mitochondria of normoblasts and reticulocytes are morphologically changed in cases of human lead poisoning and in animals intoxicated experimentally. There is general agreement that the stores of intracellular iron are increased but some confusion has arisen over the site of these increased iron stores. Thus, although several reports clearly indicate the presence of iron within the mitochondria of the normoblast (Bessis, 1958; Bessis and Breton-Gorius, 1957a, b, c, d, I959; Pernis and Bairati, 1959; Pernis, Bairati, and Guibileo, 1959; Pernis, Vigliani, Depretis, Beard and Karlsbad, 1964), Griggs (1964) states categorically that this is not so, iron is not found within the mitochondria, and he quotes a personal communication from Bessis (1963) in support of this. Indeed, in an article by Bessis and Breton-Gorius (I962), after describing the characteristic alterations of the mitochondria, these authors state, 'We have not seen any iron inside the mitochondria'.

Later work, however, leaves no doubt that iron is found within the mitochondria. Bessis and Jensen (I965) say that two types of non-haem iron may be 
found inside the abnormal sideroblast from the bone marrow of lead-poisoned animals or from patients with lead poisoning-ferritin, similar to that found in normal cells, and an abnormal type of iron which they term ferruginous micelles. The ferruginous micelles are dust-like or they occur in plaques having no constant formation. Ferritin is found within the mitochondria whereas it is found only in the cytoplasm of normal cells. The ferruginous micelles are found only within the mitochondria. In an even more recent report (Jensen, Moreno, and Bessis, 1965), the abnormalities found in the normoblasts are concisely described: mitochondria are found in abundance, they are greatly enlarged, dilated, devoid of normal cristae, and often contain large amounts of ferritin or ferruginous micelles. Ferritin is also found within the cytoplasm. (The morphological changes in the mitochondria described by Jensen et al. (1965) have also been seen in mitochondria prepared from the liver of swine fed with lead acetate over a three- to sixmonth period by Watrach (1964).)

In rat experiments where phenylhydrazine and lead are used there is an abundance of iron within the mitochondria, but iron may also be found occasionally in the mitochondria of animals fed phenylhydrazine alone (Jensen, 1965, personal communication).

Jensen (1965, personal communication) states that in 1963 Bessis was aware that iron was found in the mitochondria, and it seems therefore that Griggs' (1964) statement is at fault. The statement in the review by Bessis and Breton-Gorius (1962) quoted above may have resulted from an error in translation. The true picture is that there is no doubt that iron is found in excess in the normoblast and that a portion of the ferritin is found within the intercristal spaces of the mitochondria.

Several stages of haem synthesis are known to be facilitated by intact mitochondria (Sano, 1958b; Sano, Inoue, Tanabe, and Koike, 1959; Bessis and Jensen, 1965) and it has been suggested that they may function as an intermediate in intracellular iron metabolism (Cooper, Webster, and Harris, 1963) (Fig. 3). They are probably necessary for the continued transfer of iron from extracellular sites to normoblasts or reticulocytes (Jandl et al., 1959; Morgan and Laurell, 1963). Thus the electron microscopic findings of altered and damaged mitochondria described above may well have a correlation with impaired haem synthesis.

\section{The Coombs' Test in Lead Poisoning}

The most comprehensive study on the Coombs' test in lead poisoning was performed by Sutherland

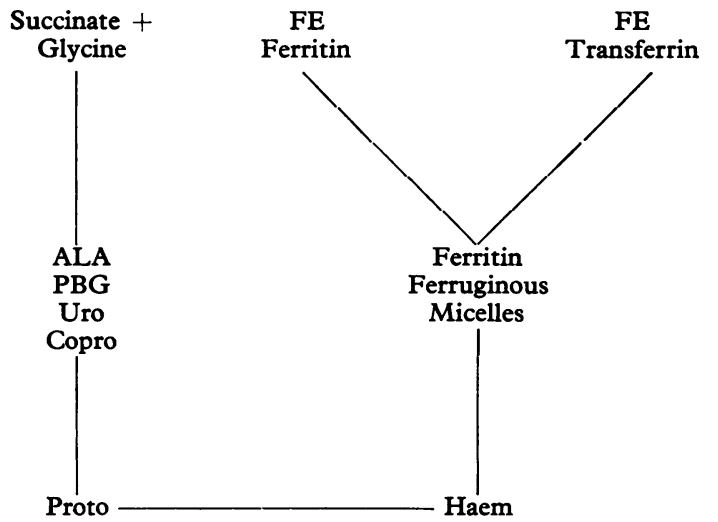

FIg. 3. Stages of haem synthesis dependent on intact mitochondria. Continuous lines indicate stages at least partially dependent on intact mitochondria (based on Bessis and Jensen, 1965).

and Eisentraut (1956). They produced acute plumbism in six dogs by injecting them with lead acetate either intravenously or intraperitoneally. In five of the six dogs so treated a positive Coombs' reaction developed within 24 hours. The sixth dog received less lead acetate than the others and it was administered intraperitoneally in this case, but nevertheless a positive Coombs' test was obtained after 13 days.

A further II dogs were given chronic plumbism and all eventually developed a positive Coombs' test, but the reaction was observed only in the upper layer of red cells after centrifugation. Since reticulocytes and stippled cells tend to be concentrated in the upper layers of centrifuged blood cells, Sutherland and Eisentraut suggested that reticulocytes may retain free globulin on the cell membrane which would account for the positive Coombs' reaction. This suggestion was confirmed in a later study by Jandl (1960).

Ten lead workers were examined by Sutherland and Eisentraut; all had a negative Coombs' reaction when whole blood was tested. Blood was obtained from a further 19 lead workers and this test was performed after the cells had been allowed to sediment. Positive reactions were obtained in the upper cells in $79 \%$ of the cases; the reaction in the lower cells or with whole blood was always negative. Pernis and Finulli (1960) also found a positive Coombs' test in the upper layer of sedimented cells from lead workers.

In cases of human lead poisoning the results are usually negative, although Crutcher (1963) did find positive reactions in three of eight cases of plumbism resulting from the drinking of 'moonshine' whisky. 
The reactions were negative when repeated Io days after treatment with EDTA. Tishkoff et al. (1958) found a negative reaction in two patients with lead poisoning, and negative findings were reported in single cases by Fullerton (1952), Karpatkin (I96I), Lane and Lawrence (1961), and Simpson et al. (I964).

Jandl and Simmons (1957) reported that the addition of lead in vitro did not cause normal red cells to become agglutinable to Coombs' serum, and it seems likely that positive reactions will occur only in cases of lead poisoning where there is a greatly increased number of reticulocytes or stippled cells present.

\section{Red Cell Survival in Lead Poisoning}

Relatively few studies on the red cell survival time in experimental or human lead poisoning have been made. The quantitative data given in the literature are summarized in Table III. The most comprehensive study has been made by Rubino, Prato, and Fiorina (1959), and it will be seen that in several cases significantly lower values than normal were obtained using both radio-chromium tagging and the method of Seip (1953).

Griggs and Harris (1958) showed that cells removed from two of four patients with lead poisoning had a significantly shorter half-life $\left(\mathrm{T} \frac{1}{2}\right), 20$ days, than the normal, 27 to 34 days. Hutchison and Stark (I96I) found one very low $T_{\frac{1}{2}}$ in the three cases they studied. After treatment with EDTA the $T_{\frac{1}{2}}$ returned to normal (Goldberg, I960). Combrisson, Desoille, and Albahary (1964) found low $T_{\frac{1}{2}}$ values in three of seven human subjects but a consistently normal value in 78 rabbits given acute and chronic plumbism experimentally. Cells from poisoned animals survived normally when transfused into control animals.

Leikin and Eng (1963) reported erythrocyte survival times in seven children with lead poisoning. The $T \frac{1}{2}$ was reduced in five of the seven patients, the shortest survival times being seen in those children with the shortest exposure to lead. None of the children studied had a concurrent iron deficiency syndrome.

Other abnormally low survival times have been reported by Sheets et al. (I95I), by Crepet et al. (I956) using Ashby's technique (I92I), and by Kaplan (1954). Karpatkin (196I) and Simpson et al. (1964) both found normal survival times in the single cases they described.

Survival times of normal red cells incubated with lead in vitro and then reinfused into the donor have been reported (Fratianne et al., 1959; Rubino et al., 1959). In two of the four experiments performed by Fratianne et al., moderately shortened survival times were found, whereas in all three cases reported by Rubino et al. shortened $\mathrm{T} \frac{1}{2}$ values were obtained.

Although there seems no doubt that in some cases of lead poisoning a shortened red cell life span is found, Rubino (1962) says that anaemia will not result until the life span is less than 40 days. Above this value compensatory erythropoiesis is sufficient to prevent anaemia developing.

There is no conclusive evidence to explain how lead produces a shortened life span in red cells, but it seems likely to be due to an effect on the developing red cells in the bone marrow, where the concentration of lead is higher than in the peripheral blood, rather than on the cell membrane of the circulating cell, as has sometimes been suggested.

\section{Stippled Cells: Effect of Lead on Erythro- poietic Cells in Bone Marrow}

Stippled cells are an invariable but by no means constant accompaniment of lead poisoning. The enumeration of the number of stippled cells in the peripheral blood has been advocated as a means of controlling exposure to lead (Lane, 1931, 1949; McCord, Holden, and Johnston, 1935) but nowadays stippling is generally regarded as an unreliable index of lead absorption (Griggs, 1964). The degree of stippling does not correlate well with the intensity of exposure and is found in a wide variety of other haematological disorders, e.g., in many haemolytic anaemias, thalassaemia, leukaemia, and after exposure to aniline, arsenic, benzene, carbon monoxide, and copper. The stippled cell count shows considerable diurnal variation (Minden and Opitz, 1957; King and Thompson, 196I), and a wide variation in the number of cells showing punctate basophilia may be found on different films from the same blood sample (Brückner, 1927; Brookfield, 1928; Dustin, 1943, 1944) depending largely on the speed of drying of the film, slowly drying films containing more stippled cells than quickly drying films. Incubating blood with New Methylene Blue ( $0.25 \%$ for 5 minutes) also increases the number of stippled cells present (Jensen et al., 1965).

Since Behrend (1899) first described the appearance of stippled cells in lead poisoning, much work has been undertaken to establish the causation and character of the stippled material. Grawitz (I900, 1906) thought that it was of cytoplasmic origin since the staining reaction of the granules was different from that of nuclear substances. This seemed to confirm the earlier views of Ehrlich (I885), Smith (I89I), and Foa (1889), although Askanazy (1907) 
TABLE III

Summary of Red Cell Survival Times in Cases of Lead Poisoning

\begin{tabular}{|c|c|c|c|c|}
\hline Author & Technique & $\begin{array}{l}\text { Survival } \\
\text { (days) }\end{array}$ & Time & Normal \\
\hline $\begin{array}{l}\text { Sheets et al. (1951) } \\
\text { Crepet et al. (1956) }\end{array}$ & $\begin{array}{l}\text { Ashby } \\
\text { Ashby }\end{array}$ & $\begin{array}{l}25 \\
95 \\
55 \\
26 \\
70\end{array}$ & $\left(\mathrm{~T} \frac{1}{2}\right)$ & $\begin{array}{l}55-60 \\
120\end{array}$ \\
\hline Griggs and Harris (1958) & ${ }^{51} \mathrm{Cr}$ & $\begin{array}{l}70 \\
20 \\
20 \\
25 \\
29\end{array}$ & $\left(T_{\frac{1}{2}}\right)$ & $27-34$ \\
\hline Rubino et al. (1959) & ${ }^{51} \mathrm{Cr}$ & $\begin{array}{l}27^{\star} \\
25 \cdot 5^{\star} \\
17 \cdot 5^{\star} \\
24 \cdot 5^{\star} \\
20^{\star} \\
12 \\
18 \cdot 5 \\
17\end{array}$ & $\left(T_{\frac{1}{2}}\right)$ & $25-31$ \\
\hline & $\begin{array}{l}\text { Transfusion of cells from patients with plumbism into } \\
\text { compatible normals. Original survival times in } \\
\text { brackets. } \\
50 \mathrm{ml} \text {. blood incubated with I } 50 \mathrm{\mu g} \text {. lead acetate for } \\
60 \mathrm{~min} \text {. Reinfused into donor. }\end{array}$ & $\begin{array}{l}17 \\
18(20) \\
16(12) \\
20(18 \cdot 5) \\
19 \\
18 \\
20 \cdot 5\end{array}$ & $\left(\mathrm{~T} \frac{1}{2}\right)$ & \\
\hline & 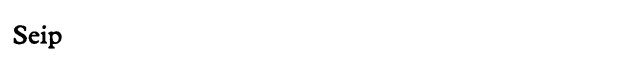 & $\begin{array}{l}20 \cdot 5 \\
42 \\
60\end{array}$ & & \\
\hline & & $\begin{array}{r}55 \\
113 \\
81\end{array}$ & & \\
\hline & & $\begin{array}{r}93 \\
73 \\
116 \\
83 \\
17 \\
135 \\
119 \\
99\end{array}$ & & IIO \\
\hline Rubino et al. (1959) & Seip & $\begin{array}{l}99 \\
22\end{array}$ & & \\
\hline & & $\begin{array}{r}\text { I IO } \\
40 \\
50 \\
95\end{array}$ & & I Io \\
\hline Fratianne et al. (1959) & $\begin{array}{l}{ }^{51} \mathrm{Cr} \\
\text { Normal cells incubated with lead chloride, reinfused } \\
\text { into donor }\end{array}$ & $\begin{array}{l}18 \\
22 \\
26 \\
28\end{array}$ & $\left(\mathrm{~T} \frac{1}{2}\right)$ & 30 \\
\hline Goldberg (1960) & $\begin{array}{l}{ }^{51} \mathrm{Cr} \\
\text { After treatment with EDTA }\end{array}$ & $\begin{array}{l}18 \\
16\end{array}$ & $\left(T_{\frac{1}{2}}\right)$ & Not given \\
\hline Hutchison and Stark (196I) & ${ }^{51} \mathrm{Cr}$ & $\begin{array}{l}26 \\
32 \\
18 \dagger\end{array}$ & $\left(T \frac{1}{2}\right)$ & Not given \\
\hline Leikin and Eng (1963) & $\begin{array}{l}{ }^{51} \mathrm{Cr} \\
\text { Children }\end{array}$ & $\begin{array}{l}13 \\
20 \\
15 \\
25 \\
22 \\
23 \\
28\end{array}$ & $\left(\mathrm{~T}_{\frac{1}{2}}\right)$ & $25-28$ \\
\hline Combrisson et al. (1964) & ${ }^{51} \mathrm{Cr}$ & $\begin{array}{l}20 \\
24 \\
20 \\
24 \\
18 \\
16 \\
11\end{array}$ & $\left(T_{\frac{1}{2}}\right)$ & $20-32$ \\
\hline Simpson et al. (1964) & ${ }^{51} \mathrm{Cr}$ & 26 & $\left(T_{\frac{1}{2}}\right)$ & $25-30$ \\
\hline
\end{tabular}

Unless otherwise stated, auto-survival times were determined.

^Also described by Crepet et al. (1956). †Also described by Goldberg (1960). 
later advanced the theory that the granules were nuclear fragments.

There was much controversy among early workers whether stippling represented a regenerative or a degenerative change. Engel (1900) thought it was a regenerative change because of the appearance of stippled cells in the embryo. This view was supported by Askanazy (1907), König (1910), Naegeli (I93I), and Young and Osgood (1935). Those who championed the opposite view were Weidenreich (1903), Jolly (1907), and Grawitz, Key, and Pappenheim (1919). These last authors based their conclusions principally on the fact that they were unable to demonstrate stippled cells in the bone marrow of lead-poisoned animals. Key (1924) was also unable to find stippled cells in the bone marrow of lead-poisoned animals, and Bell et al. (1925) could not detect stippled cells even in the marrow of animals which had died from lead poisoning. Since then, however, many workers have succeeded in demonstrating punctate basophils in the marrow from cases of human and animal lead poisoning (Young and Osgood, 1935; Klima and Seyfried, 1937; Duvoir, Pollet, Gaultier, and Ménétrier, 1938; de Weerdt, 1939; Thaddea, 1940; Bentsáth and Varga, 1940; Henning and Keilhack, 1940; Kopasz, 1943; Albahary, 1944-45; Movitt, 1945; Saita, 1946; Leitner, 1949; McFadzean and Davis, 1949; Fullerton, 1952; Pirrie, 1952; Morel, Roche, and Baron, 1954; Beritić and Vandekar, 1956; David, 1959). Albahary (1944-45) gave lead acetate intravenously to volunteers and found stippled cells in the marrow before they appeared in the peripheral blood. Generally, more stippled cells are found in the bone marrow than in the peripheral blood, suggesting that lead exerts its effect primarily on red cell precursors in the bone marrow rather than on the circulating red cell.

Brookfield (1928) thought that stippled cells were young cells altered by a degenerative process, and he produced some evidence to confirm the earlier work of Schwarz and Hefke (1923), Brückner and Spatz (1926, 1927), and Brückner (1927) that stippling as such is not present while the blood cells are circulating but appears only after the blood has been shed. He was unable to demonstrate stippling in fresh blood as some earlier workers had done (Dietrich, I910; Ferrata and Boselli, 1910). Later, Dustin (1943, 1944) confirmed Brookfield's work and indicated that stippling occurs only when cells containing the necessary precursors are subjected to certain manipulations prior to microscopic examination.

Ferrata (1933) thought that the stippled material was derived from the red cell membrane but Whitby and Britton (1933) were of the opinion that stippled cells were reticulocytes in which the basophilic material had been altered by the lead. This view was corroborated by Haenel (I949) and by Baikie and Pirrie (1958) who also thought that the stippled cell was a modified reticulocyte. Sroczyński (I962), however, stated that stippled cells were not reticulocytes, but later work by Jensen et al. (1965) indicated that there was almost certainly some relationship between the two types of cell.

McFadzean and Davis (1947, 1949) found that stippled cells frequently contained iron-staining inclusion bodies which they thought were related to the basophilic stippling of plumbism although Doniach, Grüneberg, and Pearson (I943) had previously reported that there was no such relationship. Dacie and Doniach (1947) demonstrated that the siderotic granules in red cells may be basophilic but they noticed that red cells showing classical punctate basophilia gave a negative iron-staining reaction. Pirrie (1952) reported that a varying proportion of the basophilic granules of stippled cells gave a positive iron-staining reaction, but Douglas and Dacie (1953) found that few, if any, of the granules of diffuse punctate basophilia were iron-containing. In some pathological states, however, erythroblasts showing coarse basophilia may give a positive ironstaining reaction (Sundberg and Broman, 1955). Beritić, Grgic, and Sirec (1957) found no correlation between the incidence of stippled cells and ironcontaining cells, although basophilic granules were frequently found in siderocytes and sideroblasts. In a later paper, Beritić (1963) was able to demonstrate three distinct types of cell in patients with lead poisoning: those containing basophilic, iron-negative granules only, those containing iron-positive, non-basophilic granules only, and those containing both types of granule. This paper considerably clarified the confused situation, Beritic concluding that since the two types of granule were constantly found together, it was justifiable to conclude that both phenomena were intimately related to the same metabolic disturbance. He stressed, however, that the iron-positive granules were not to be regarded as cytochemical variants of the iron-negative granules.

The comprehensive studies of Dustin (1943, 1944) indicated that the basophilic granules were composed of ribonucleoproteins, and the electron microscope studies of Sano (1955) showed that the stipple material might be aggregates of ribonucleic acid (RNA) around the mitochondria. He later showed (Sano, 1958a) that the oxygen consumption of stippled cells was much greater than that of mature cells, thus confirming the results of Baikie and Valtis (1954). RNA was also found in stippled cells by Sroczyński (1962) and David (1963). 
Bessis and Breton-Gorius (1962) thought that the altered mitochondria found in the normoblasts in lead poisoning might constitute the basophilic granulation, but recent papers by Jensen and his colleagues (Jensen and Moreno, 1964; Jensen $e t$ al., 1965) indicate that the stipple granules are composed of altered ribosomes and do not include mitochondria. After extensive electron microscope studies they concluded that the three morphological entities, reticulocytes, diffuse polychromasia, and basophilic stippling, were largely the result of different manipulations in preparation for optical or electron microscopy, and this accounted for the multiplicity of conclusions reported regarding the nature of the stipple material. They confirmed the results of Beritic (1963) regarding siderocytes and stippled cells and showed that non-haem iron was not an essential component of basophilic stippling.

Lead has been shown to produce definite morphological changes in the erythroid cells of the bone marrow. The occurrence of stippled cells in the marrow has been mentioned above. In addition many authors have noted the presence of megaloblasts (or macroblasts) in lead-poisoned animals (Dumas, 1903; Ophüls, 1915; Seiffert and Arnold, 1928; Speransky and Sklianskaja, 1928; Fontana and Stazzi, 1933; Klima and Seyfried, 1937; Sroczyński, 1962) and in cases of human plumbism (Cadwalader, 1906; Pellegrini, 1935; Pelaez Redondo, I94I; Garta, I949; Heilmeyer and Begemann, I95I) although Beritić and Vandekar (1956) in an extensive study of 19 cases of lead poisoning were unable to find megaloblastosis in a single instance. Instead, they discovered a great preponderance of polyploid erythroblasts, mostly bi-nuclear (incidence $2 \cdot 2$ to $13.7 \%$ ), and they suggested that these cells may have been confused with megaloblasts by earlier workers. Beritić and Vandekar were apparently the first authors to describe polyploid erythroblasts in lead poisoning, and their finding was subsequently confirmed by David (1959).

Nuclear changes have been noted by several authors (Cadwalader, 1906; Leitner, 1945; de Weerdt, 1939; Rohr, 1949; Fullerton, 1952; Beritić and Vandekar, 1956; Moeschlin, 1957; David, I959), the most complete description of the changes observed being that given by Beritić and Vandekar. They believed that the nuclear alterations were closely related to the polyploidy they observed. They thought that the fusion of chromosomes did not permit the nucleus of the late normoblast to complete its division, but instead a plurinuclear erythroblast with karyorrhexis resulted.

Abnormalities in mitosis have been noted by other authors (Morel et al., 1954; Kienle, 1943; Omel- janienko, 1954). In a series of animal experiments Rondanelli, Gorini, Colombi, and Verga (1958). found that lead had a definite mitostatic activity on erythroblast nuclei at metaphase. They considered that this antimitotic effect of lead might be an element in the pathogenesis of the anaemia of lead poisoning.

\section{Conclusion}

It seems probable that there is no single factor responsible for the production of the anaemia of lead poisoning. Much of the evidence which has been put forward to show that the anaemia is haemolytic in character is equivocal, although there can be no doubt that high concentrations of lead can produce morphological changes in mature circulating red cells both in vitro and in vivo.

On the other hand, there seems no doubt that lead has a profound effect on red cell precursors in the bone marrow, producing morphological changes and also causing defective haemoglobinization by inhibiting haem synthesis, and any changes induced in the peripheral red cells may be the results of this primary action on erythroblastic cells in the marrow.

It is true to say that the precise cause of the anaemia of lead poisoning is still not known, but, in the author's opinion, the answer is likely to be found in the effect of lead on a complex of enzymes, both those responsible for haem synthesis and those concerned with glycolysis.

\section{REFERENCES}

Albahary, C. (1944-45). Sang., 16, 34 r.

Aldrich, R. A., Labbe, R. F., and Talman, E. L. (1955). Amer. F. med. Sci., 230, 675.

Allen, D. W., and Jandl, J. H. (1960). Blood, 15, 7 r.

Andral and Gavarret (1840). Ann. Chim. et Phys., 75, 309.

Ashby, W. (1921). F. exp. Med., 34, 127.

Askanazy, S. (1907). Z. klin. Med., 64, 288.

Aub, J. C., Fairhall, L. T., Minot, A. S., and Reznikoff, P. (1925). Medicine, 4, $\mathrm{I}$.

,-- and - (1926). Lead Poisoning. Williams \& Wilkins, Baltimore.

-, Minot, A. S., Fairhall, L. T., and Reznikoff, P. (1924). f. Amer. med. Ass., 83, 588.

$\longrightarrow$, and Reznikoff, P. (1924). Э. exp. Med., 40, 189.

$\longrightarrow,-$, and Smith, D. E. (1924). Ibid., 40, 151 .

Baikie, A. G. (1954). Blood, 9, 46r.

— and Pirrie, R. (1958). Scot. med. F., 3, 264.

- and Valtis, D. J. (1954). Brit. F. exp. Path., 35, 434.

Baron, J. (1954). Thesis, Lyons.

Bastrup-Madsen, P. (1950). Lancet, 2, 171.

Beck, E., Lanini, G., and Béraud, T. (1955). Helv. med. Acta, 22, 442 . 
Behrend (1899). Dtsch. med. Wschr., 25, Vereins-Beilage No. 42, 254.

Bell, W. B. (1930). Some Aspects of the Cancer Problem. Baillière, Tindall and Cox, London.

—, Williams, W. R., and Cunningham, L. (1925). Lancet, 2, 793.

Bénard, H., Gajdos, A., and Gajdos-Török, M. (1958). C. R. Soc. Biol. (Paris), I52, 296.

Bentsáth, A., and Varga, S. (1940). Dtsch. med. Wschr., 66, I 194.

Beritić, T. (1963). Brit. F. Haemat., 9, 185.

-, Grgic, Z., and Sirec, A. (1957). Proc. XII Int. Congr. Occup. Health, Helsinki, 1957.

—, and Vandekar, M. (1956). Blood, II, II4.

Bessis, M. (1958). Bull. Acad. nat. Méd. (Paris), 142, 629.

- and Breton-Gorius, J. (1957a). C. R. Acad. Sci. (Paris), 244, 2846.

— and - (1957b). Rev. Hémat., 12, 43.

- and - (1957c). Sem. Hôp. Path. et Biol., 33, 4II.

- and - (1957d). C. R. Soc. Biol. (Paris), 151, 275.

- and - (1959). Blood, 14, 423.

- and - (1962). Ibid., 19, 635 .

- and Jensen, W. N. (1965). Brit. F. Haemat., I1, 49

Björkman, S. E. (194I). Acta med. scant., 108, 568.

Bouchard, C. (1873). C. R. Soc. Biol. (Paris), 5 Ser., 5, 358.

Boyett, J. D., and Butterworth, C. E. (1962). Amer. F. Med., 32, 884 .

—, Pittman, J. A., and Butterworth, C. E. (1960). Clin. Res., 8, 52.

Brookfield, R. W. (1928). F. Path. Bact., 31, 277.

Brückner, H. (1927). Arch. Hyg. (Berl.), 98, 95.

—, and Spatz, R. (1926). Ibid., 97, 277.

- and (1927). Arb. Reichs gesundh.-Amte, 58, $49 \mathrm{I}$.

Brüschke, G. (1959). Dtsch. Gesundh.-wes., 14, I059.

(I962). Folia Haemat. (Lpz.), 78, 286.

Buczkowski, M. (1964). Int. Arch. Gewerbepath. Gewerbehyg., 20, 537 .

Burka, E. R., and Marks, P. A. (1964). F. molec. Biol., 9, 439.

Caccuri, S., Pecora, L., Fati, S., and Vecchione, C. (1958). Arch. Mal. prof., 19, 34I.

Cadwalader, W. P. (1906). Bull. Ayer. clin. Lab., r, no. 3, p. 44 .

Cantarow, A., and Trumper, M. (1944). Lead Poisoning. Williams and Wilkins, Baltimore.

Chisolm, J. J. (1964). F. Pediat., 64, 174.

Clarkson, T. W., and Kench, J. E. (I958a). Biochem. f., 69, 432.

— and - (1958b). Brit. 7. industr. Med., 15, I15.

Combrisson, A., Desoille, H., and Albahary, C. (I964). Proc. XIV Int. Cong. Occup. Health, Madrid, 1963, Vol. 2, p. 755 .

Comfort, A., and Weatherall, M. (1953). Biochem. F., 54, 247.

Cooper, R. G., Webster, L. T., and Harris, J. W. (I963). F. clin. Invest., 42, 926.

Crepet, M., Rubino, G., and Gobbato, F. (1956). Proc. 2 Ist Cong. Nat. di Med. del Lavoro.

Crosby, W. H. (1957). Blood, 12, 165.

- (1959). Ibid., 14, 399.

Crutcher, J. C. (1963). Ann. intern. Med., 59, 707.

Dacie, J. V., and Doniach, I. (1947). F. Path. Bact., 59, 684.

David, A. (1959). Arch. Gewerbepath. Gewerbehyg., 17, 329.

- (1963). Caso. Lék. čes., 102, 69.

Davidson, L. S. P. (1932). Quart. F. Med., r, 543.

de Kretser, A. J., and Waldron, H. A. (1963). Brit. F. industr. Med., 20, 316.

and - (1965). Ibid., in press.

Dérobert, L., and Hadengue, A. (1947). Ann. Méd. lég., 27, I 30.

de Weerdt, W. (1939). Rev. belge, Sci. méd., II, 297.

Dietrich, A. (1910). Folia haemat. (Lpz.), 9, 297.
Dobriner, K., and Rhoads, C. P. (1940). Physiol. Rev., 20, 416.

Doniach, I., Grüneberg, H., and Pearson, J. E. G. (1943). F. Path. Bact., 55, 23.

Douglas, A. S., and Dacie, J. V. (1953). F. clin. Path., 6, 307.

Dresel, E. I. B., and Falk, J. E. (1954). Biochem. F., 56, I 56. and - (1956a). Ibid., 63, 72 .

-

Dumas, R. (1903). Arch. gén. Méd., 192, 2567.

Dustin, P. (1943). Arch. Biol. (Liège), 55, 475.

- (1944). Ibid., 55, 285.

Duvoir, M., Pollet, L., Gaultier, M., and Ménétrier, J. (1938). Sang., 12, 906.

Ehrlich, P. (1885). Charité-Ann., 10, 136.

Engel, C. S. (1900). Berl. klin. Wschr., 37, 55 .

Eriksen, L. (1955). Scand. F. clin. Lab. Invest., 7, 80.

Falk, J. E., and Dresel, E. I. B. (1952). I $e^{e}$ Congr. int. Biochimie, Paris, 1952. Résumés de Communications, p. 8.

Ferrata, A. (1933). Le Emopatie, Vol. I., part I. Società Editrice Libraria, Milan. and Boselli, S. (I910). Folia haemat. (Lpz.), ro, 45 I.

Fici, V. (1920). Folia med. (Napoli), 6, 587.

(1921a). Ibid., 7, 82. (1921b). Ibid., 7, 20I.

Foa, P. (1889). Beitr. path. Anat., 5, 253.

Fontana, A., and Stazzi, S. (1933). Clin. med., 14, 3 I I.

Fratianne, R. B., Griggs, R. C., and Harris, J. W. (1959). Clin. Res., 7, 384.

Fullerton, J. M. (1952). Brit. med. f., 2, I17.

Gajdos, A., and Gajdos-Török, M. (1958). Sang., 29, 444.

Gajdos-Török, M., Gajdos, A., and Bénard, H. (1958). C. $R$. Soc. Biol. (Paris), 152, I689.

$\longrightarrow,-$ and - (1960). Ibid., 154, 508.

Garta, I. (1949). Wien. klin. Wschr., 6r, 6 ro.

Gaultier, M., Fournier, E., and Gervais, P. (1962). Bull. Soc. méd. Hôp. (Paris), I13, 863.

Gérard, A., Guerrin, F., and Roussel, P. (1964). Arch. Mal. prof., 25, 346.

Gilligan, D. R., Altschule, M. D., and Katersky, E. M. (1941). F. clin. Invest., $20,177$.

Goldberg, A. (1960). Proc. $2^{e}$ Colloque Int. de Biol. de Saclay.

-, Ashenbrucker, H., Cartwright, G. E., and Wintrobe, M. M. (1956). Blood, 11, 82 I.

Goldblatt, M. W. (1955). Brit. F. industr. Med., 12, I.

and Goldblatt, J. (1956). In Industrial Medicine and Hygiene, Vol. 3. Ed. Merewether, E. R. A. Butterworth, London.

Gould, S. E., Kullman, H. J., and Shecket, H. A. (1937). Amer. F. med. Sci., 194, 304.

Grawitz, E. (1900). Berl. klin. Wschr., 37, I81.

(1906). Klinische Pathologie des Blutes, 3rd ed. Leipzig.

, Key, J. E., and Pappenheim, A. (1919). Folia haemat. $(L p z), 24,86$.

Grazianni, G., Fusco, M., and Rossi, L. (1954). Folia med. (Napoli), 37, 643 .

—, Pecora, L., and Rossi, L. (1956). Ibid., 39, 217.

Greenough, W. B., Peters, T., and Thomas, E. D. (1962). 7. clin. Invest., 4I, I I 16.

Griggs, R. C. (1964). Progr. Hemat., 4, I17.

- and Harris, J. W. (1958). Clin. Res., 6, 188.

Grinstein, M., Bannerman, R. M., and Moore, C. V. (1959). Blood, 14, 476.

—, Kamen, M. D., Wikoff, H. M., and Moore, C. V. (1950a). F. biol. Chem., 182, 715 .

-, Wikoff, H. M., Pimenta de Mello, R., and Watson, C. J. (1950b). Ibid., 182, 723.

Grotepass, W. (1932). Hoppe-Seylers Z. physiol. Chem., 205, I93. 
Haeger-Aronsen, B. (1960). Scand. F. clin. Lab. Invest., 12, Suppl. 47.

Haenel, U. (1949). Acta haemat. (Basel), 2, 298.

Harris, J. W. (1963). The Red Cell, Production, Metabolism, Destruction: Normal and Abnormal. Harvard University Press, Cambridge, Mass.

- and Greenberg, M. S. (1954). Clin. Res. Proc., 2, 55.

Heilmeyer, L. (1959). Dtsch. med. Wschr., 84, r76r.

and Begemann, H. (I95I). Blut und Blutkrankheiten. Springer, Berlin

Henderson, L. L. (1952). Arch. intern. Med., 89, 967.

Henning, N., and Keilhack, H. (1940). Dtsch. med. Wschr., 66, 323 .

Heubel, E. (1871). Pathogenese und Symptome der chronischen Bleivergiftung. Hirschwald, Berlin.

Hijmans van den Bergh, A. A. (193I). Wien. med. Wschr., 81, 1359.

Holeček, V. (1957). Brit. f. industr. Med., 14, 198.

Hutchison, H. E., and Stark, J. M. (I96I). f. clin. Path., 14,548 .

Jandl, J. H. (1960). F. Lab. clin. Med., 55, 663.

-, Inman, J. K., Simmons, R. L., and Allen, D. W. (1959). 7. clin. Invest., 38, $16 \mathrm{I}$.

and Simmons, R. L. (1957). Brit. F. Haemat., 3, I9.

- and Tomlinson, A. S. (1958). F. clin. Invest., 37, 1202.

Jensen, W. N., and Moreno, G. (1964). C. R. Acad. Sci. (Paris), 258, 3596.

,-- , and Bessis, M. (1965). Blood, 25, 933.

Jolly, J. (1907). Arch. Anat. micr., 9, 133.

Joyce, C. R. B., Moore, H., and Weatherall, M. (1954). Brit. F. Pharmacol., 9, 463 .

Kaplan, E. (1954). Amer. F. Dis. Child., 88, 808.

-, Zuelzer, W. W., and Mouriquand, C. (1954). Blood, 9, 203.

Kark, R., and Meiklejohn, A. P. (1942). F. clin. Invest., 21, $9 \mathrm{I}$.

Karlog, O., and Møller, K. O. (1958). Acta pharmacol. $(K b h), 15,8$.

Karpatkin, S. (I96I). Arch. environm. Hlth, 2, 679.

Kassenaar, A., Morell, H., and London, I. M. (1957). $\mathcal{f}$. biol. Chem., 229, 423.

Kench, J. E., Gillam, A. E., and Lane, R. E. (1942). Biochem. F., 36, 384 .

—, Lane, R. E., and Varley, H. (1952). Brit. f. industr. Med., 9, 133 .

Key, J. A. (1924). Amer. F. Physiol., 70, 86.

Kienle, F. (1943). Die Sternalpunktion in der Diagnostik. Thieme, Leipzig.

Kin, S. (1939). F. med. Coll. Keijo, 9, ror.

King, E., and Thompson, A. R. (I96I). Ann. occup. Hyg., 3, 247.

Klein, J. R. (1962). Amer. F. Physiol., 203, 971.

Klima, R., and Seyfried, H. (1937). Folia haemat. (Lpz.), $57,283$.

König, H. (1910). Ibid., 9, 278.

Kopasz, E. (1943). Ibid., 67, 292.

Korst, D. R., Frenkel, E. P., and Wilhelm, J. E. (1962). In Erythropoiesis, ed. L. D. Jacobsen and M. Doyle. Grune and Stratton, New York.

Laennec, R. T. H. (183I). Traité de L'auscultaticn médiate, 3rd ed. Chaudé, Paris.

Lane, R. E. (1931). F. industr. Hyg., 13, 276.

- (1949). Brit. F. industr. Med., 6, 125.

Lane, C. Rickword, and Lawrence, A. (196I). Brit. med. F., 2, 939.

Laporte, A., Meyer, A., and Bousser, J. (1939). Bull. Soc. méd Hôp. Paris, 55, 955.

Larizza, P., and Ventura, S. (1954). Medicina (Parma), 4, I.

Leikin, S., and Eng, G. (1963). Pediatrics, 31, 996.
Leitner, S. J. (1945). Die intravitale Knochenmarksuntersuchung: Die Hämatologie im Lichte der Sternalpunktion. Schwabe, Basel.

- (1949). Bone Marrow Biopsy. Eng. trans. rev. and ed. C. J. C. Britton and E. Neumark. Churchill, London.

Lemberg, R., and Legge, J. W. (1949). Hematin Compounds and Bile Pigments. Interscience Publishers, New York.

London, I. M., and West, R. (1950). F. biol. Chem., r84, 359. , Shemin, D., and Rittenberg, D. (I950). Ibid., I84, 35 I.

Lothe, K., and Falbe-Hansen, I. (1963). Clin. Sci., 24, 47.

Lourau, M. (1946). Sang., 17, 517.

- (1947a). Ibid., 18, 96.

(1947b). Bull. Soc. Chim. biol. (Paris), 29, 34

(1947C). Ibid., 29, 53 I.

Lovisetto, P., Sibour, F., and Turco, G. L. (1957). Boll. Soc. ital. Biol. sper., 33, 149.

McCord, C. P., Holden, F. R., and Johnston, J. (I935) Amer. F. publ. Hlth, 25, 1089.

McFadzean, A. J. S., and Davis, L. J. (1947). Glasg. med.f., 28, 237.

- and - (1949). Quart. F. Med., 18, 57.

MacGibbon, B. H., and Mollin, D. L. (1965). Brit. F. Haemat., 11, 59.

Mann, T. S. (1962). Scot. med. F., 7, 36.

Maugeri, S. (1940). Med. d. Lavoro, 31, 97.

Maurel, E. (1912). C. R. Soc. Biol. (Paris), 73, 550.

Maxwell, L. C., and Bischoff, F. (I929a). F. Pharmacol. exp. therap., 36, 279.

- and - (1929b). Ibid., 37, 413.

Mellemgård, K., and Sørensen, G. (1955). Ugeskr. Lœg., I17, 127 .

Minden, H., and Opitz, H. (1957). Arch. Gewerbepath. Gewerbehyg., 15, 230.

Moeschlin, S. (1957). Schweiz. med. Wschr., 87, I091.

Mollin, D. L. (1965). Brit. F. Haematol., I, 41.

Morel, P., Roche, L., and Baron, J. (1954). Arch. Mal. prof., $15,308$.

Morgan, E. H., and Laurell, C.-B. (1963). Brit. F. Haemat., 9, $47 \mathrm{I}$.

Movitt, E. R. (1945). Amer. F. clin. Path., 15, 557.

Naegeli, O. (I93I). Blutkrankheiten und Blutdiagnostik, 5th ed. Springer, Berlin.

Omeljanienko, L. M. (I954). Thesis, Moscow.

Ophüls, W. (I915). Amer. F. med. Sci., 150, 518.

Paolino, W., Resegotti, L., Sartoris, S., and Infelise, V. (1963). Minerva med., 54, 527.

Passow, H., and Tillmann, K. (1955). Pflügers Arch. ges. Physiol., 262, 23.

Pearse, H. E. (1926). Arch. intern. Med., 37, 715.

Pecora, L. (1954). Folia med. (Napoli), 37, 82.

_- Fati, S., and Vecchione, C. (1960). Ibid., 43, 685.

- - Molé, R., and Pesaresi, C. (1963). Proc. XIV Int. Congr. Occup. Health, Madrid, 1963, Vol. III, p. 1068.

Pelaez Redondo, J. (194I). Rev. Clin. esp., 2, 426.

Pellegrini, G. (1935). Rif. med., 51, 589.

Pernis, B., and Bairati, A. (1959). Med. d. Lavoro, 50, 447

- - - and Giubileo, M. (1959). Ibid., 50, 358.

- and Finulli, M. (1960). Ibid., 51, 48I.

_ Vigliani, E. C., Depretis, Beard, R., and Karlsbad, G. (1964). Proc. XIV Int. Cong. Occup. Health, Madrid, I963, Vol. II, p. 798.

Pirrie, R. (1952). F. Path. Bact., 64, 21 I.

Prader, A. (I948). Schweiz. med. Wschr., 78, 273.

Prankerd, T. A. J. (196I). The Red Cell. Blackwell, Oxford.

Rauch, H. (1922). Z. ges. exp. Med., 28, 50.

Riedl, L. (1941). Wien. med. Wcshr., 91, 697.

Rimington, C. (1936). Onderstepoort f. vet. Res. Sci., 7, 567.

- (1938). C. R. Trav. Lab. Carlsberg (Sér. chim.), 22, 454 
- (1951). In Ciba Foundation Conference on Isotopes in Biochemistry. Churchill, London.

(1952). Acta med. scand., 143, 16r.

Roche, L., Lejeune, E., Tolot, F., Mouriquand, C., Baron, J., Goineau, M., and Soubrier, J. (1960). Arch. Mal. prof., 21, 329.

Rohr, K. (1949). Das menschliche Knochenmark, and ed. Thieme, Stuttgart.

Roth, E. (1935). Z. klin. Med., 129, 123.

Rondanelli, E. G., Gorini, P., Colombi, R., and Verga, L. (I958). Haematologica, 43, 1077.

Rubino, G. F. (I962). Panminerva med., 4, 340.

— and Prato, V. (1955). G. Accad. Med. Torino, 118, 23.

$\longrightarrow,-$, and Fiorina, L. (1956). Folia med. (Napoli), 39, III 7 .

$\longrightarrow, \frac{1}{\text {, and }}-$ (1959). Ibid., 42, $\mathrm{x}$.

_, Pagliardi, E., Prato, V., and Giangrandi, E. (1958). Brit. F. Haemat., 4, 103.

Saita, G. (I946). Med. d. Lavoro, 37, 207.

- -, Fiocchi, F., and Cattaneo, E. (1952). Med. d. Lavoro, 43, 99.

—_ and Moreo, L. (1959). Ibid., 50, 37.

- - - and Petrocchi, L. (1956). Folia med. (Napoli), 39, 217.

Sano, S. (1955). Acta haemat. jap., 18, 631.

- (1958a). Ibid., 21, Suppl. 2.

- (1958b). Ibid., 21, 157 .

- (1958c). Acta haemat. jap., 21, 337.

—, Inoue, S., Harada, A., and Orita, Z. (1960). Acta Sch. med. Univ. Kioto, fap., 36, 182.

$\longrightarrow, \frac{}{275}$ Tanabe, Y., and Koike, S. (1959). Science, 129, 275.

Schmid, R., Hanson, B., and Schwartz, S. (1952). Proc. Soc. exp. Biol. (N.Y.), 79, 459.

$\longrightarrow$, Schwartz, S., and Watson, C. J. (1950). Ibid., 75, 705.

Schmidt-Kehl, L. (1927). Arch. Hyg. (Berl.), 98, I.

Schwartz, H. C., Cartwright, G. E., Smith, E. L., and Wintrobe, M. M. (1959). Blood, 14, 486.

Schwarz, L., and Hefke, H. (1923). Dtsch. med. Wschr., 49, 212.

Seiffert, G., and Arnold, A. (1928). Arch. Hyg. (Berl.), 99, 272.

Seip, M. (1953). Acta med. scand., Suppl. 282.

Sheets, R. F., Janney, C. D., Hamilton, H. E., and DeGowin, E. L. (1951). F. clin. Invest., 30, 1272.

Simpson, J. A., Seaton, D. A., and Adams, J. F. (1964). $\mathcal{F}$. Neurol. Neurosurg. Psychiat., 27, 536.

Smith, T. (1891). Trans. Ass. Amer. Phycns., 6, 263.

Speransky, J., and Sklianskaja, R. (1928). Folia haemat. (Lpz.), 36, 289.

Sroczyński, J. (1959). Postepy Hig. Med. dósw., 13, 74 I.

-- (1962). Pol. Arch. Med. wewnęt, 32, 673.
- (1963). Postepy Hig. Med. dósw., 17, 585.

- , Jonderko, G., and Watras, J. (1964). Proc. X Congr. Int. Soc. Haematol., Stockholm, 1964.

Strickland, S. C. (1948). N. S. med. Bull., 27, 206.

Sümegi, I., Goreczky, L., and Róth, I. (1956). Acta morph. Acad. Sci. hung., 7, 183.

Sundberg, R. D., and Broman, H. (1955). Blood, 10, 160.

Sutherland, D. A., and Eisentraut, A. M. (1956). Ibid., I1, IO24.

Tanquerel des Planches, L. (1839). Traités des maladies de plomb, ou saturnines. Paris.

Teisinger, J., Zumanova, R., and Zezula, I. (1958). A. M. A. Arch. industr. Hlth, 17, 295.

Thaddea, S. (1940). Dtsch. med. Wschr., 66, 992.

Tishkoff, G. H., Granville, N. B., Rosen, R., and Dameshek, W. (1958). Acta Haemat. (Basel), 19, 32 I.

Trakatellis, A. C., Heinle, E., Montjar, M., Axelrod, A. E., and Jensen, W. N. (1965). Arch. Biochem., in press.

Vannotti, A. (1954). Porphyrins. Hilger and Watts, London.

- and Imholz, A. (1939). Z. ges. exp. Med., 106, 597.

Velicogna, A. (I933). Med. d. Lavoro, 24, I.

Vigliani, E. C., and Angeleri, C. (1935). Clin. med. ital., 66,5 .

Vincent, P. C. (1958). Aust. F. exp. Biol. med. Sci., 36, 589.

and Blackburn, C. R. B. (I958). Ibid., 36, 47I.

Vorhaus, E. F., and Turner, J. C. (1957). Blood, 12, 469.

Wade, J. F., and Burnum, J. F. (1955). Ann. intern. Med., 42, $25 \mathrm{I}$.

Waldron, H. A. (1964). F. clin. Path., 17, 405.

Watrach, A. M. (1964). f. Ultrastruct. Res., 10, 177.

Watson, C. J. (1936). f. clin. Invest., 15, 327.

- (1937). Ibid., 16, 383.

— (1950). Arch. intern. Med., 86, 797.

- (1964). In Diseases of Metabolism. Ed. G. Duncan, 5th ed., pp. 850-887. Saunders, Philadelphia.

and Larson, E. A. (1947). Physiol. Rev., 27, 478.

Watson, R. J., Decker, E., and Lichtman, H. C. (1958). Pediatrics, 21, 40.

Weatherall, M. (1952). Biochem. F., 52, 683.

Weidenreich, F. (1903). Ergebn. Anat. Entwickl.-Gesch., 13, I.

Weiss, L. (1957). F. biophys. biochem. Cytol., 3, 599.

Westerman, M. P., Pfitzer, E. A., and Jensen, W. N. (1963). Clin. Res., II, 201.

Whitby, L. E. H., and Britton, C. J. C. (1933). Lancet, I, II 73.

Wilkinson, J. H. (1962). An Introduction to Diagnostic Enzymology, Arnold, London.

Wolman, I. J., and Bongiovanni, A. M. (1956). Amer. $\mathcal{F}$. med. Sci., 232, 688.

Young, R. H., and Osgood, E. E. (1935). Arch. intern. Med., $55,186$.

Zegarski, W. (1963). Acta biol. Med. Soc. Sci. Gedan., 7, 33. 